ISSN: 2302-8556

E-Jurnal Akuntansi Universitas Udayana

Vol.25.2.November (2018): 1506-1533

DOI: https://doi.org/10.24843/EJA.2018.v25.i02.p26

\title{
Sosialisasi Perpajakan Memoderasi Pengaruh Kesadaran Wajib Pajak dan Sanksi Perpajakan pada Kepatuhan Wajib Pajak
}

\author{
I Made Gilang Hartana ${ }^{1}$ \\ Ni Ketut Lely Aryani Merkusiwati ${ }^{2}$
}

${ }^{1}$ Fakultas Ekonomi dan Bisnis Universitas Udayana (Unud), Bali, Indonesia email: imadegilanghartana@yahoo.co.id / Telp: 081936681766

${ }^{2}$ Fakultas Ekonomi dan Bisnis Universitas Udayana (Unud), Bali, Indonesia

\begin{abstract}
ABSTRAK
Pembangunan suatu daerah sangat bergantung kepada sektor pajaknya. Pajak merupakan kewajiban yang harus dibayar oleh masyarakat kepada pemerintah daerah untuk membiayai kegiatan pembangunan di segala bidang. Tujuan penelitian ini adalah untuk mengetahui pengaruh kesadaran wajib pajak dan sanksi perpajakan pada kepatuhan wajib pajak kendaraan bermotor dengan sosialisasi perpajakan sebagai pemoderasi. Penelitian ini dilaksanakan di Kantor Bersama SAMSAT Tabanan. Jumlah sampel yang digunakan dalam penelitian ini sebanyak 100 orang yang diperoleh dengan metode nonprobability sampling dengan teknik purposive sampling. Pengumpulan data dilakukan dengan metode obsevasi nonpartisipan dan kuesioner. Teknik analisis data dilakukan dengan menggunakan analisis regresi linier berganda dan Moderated Regression Analysis. Hasil penelitian yang dilakukan menunjukkan bahwa kesadaran wajib pajak dan sanksi perpajakan berpengaruh positif pada kepatuhan wajib pajak kendaraan bermotor di Kantor Bersama SAMSAT Tabanan. Penelitian ini juga menemukan bahwa sosialisasi perpajakan mampu memperkuat pengaruh kesadaran wajib pajak pada kepatuhan wajib pajak kendaraan bermotor di kantor Bersama SAMSAT Tabanan.
\end{abstract}

Kata kunci: kesadaran, sanksi, sosialisasi, kepatuhan

\begin{abstract}
The development of an area is heavily dependent on the tax sector. The purpose of this study is to determine the effect of taxpayer awareness and tax sanctions on compliance with motor taxpayers with the socialization of taxation as a moderator. This research was conducted at SAMSAT Tabanan Joint Office. The number of samples used in this study were 100 people obtained by nonprobability sampling method with purposive sampling technique. Data were collected by non-participant observation method and questionnaire. Data analysis technique is done by using multiple linear regression analysis and Moderated Regression Analysis. The results of the research show that taxpayers' awareness and tax sanctions have a positive effect on motor vehicle taxpayer compliance in SAMSAT Tabanan Office. This study also found that the socialization of taxation can strengthen the influence of taxpayer awareness on the compliance of motor vehicle taxpayers in the joint office of SAMSAT Tabanan.

Keywords: awareness, sanction, socialization, compliance
\end{abstract}

\section{PENDAHULUAN}

Indonesia merupakan salah satu negara berkembang dengan jumlah sumber daya manusia yang sangat banyak. Banyaknya sumber daya manusia membuat pemerintah harus terus menerus melaksanakan pembangunan nasional untuk 
I Made Gilang Hartana dan Ni Ketut Lely Aryani Merkusiwati. Sosialisasi...

mewujudkan kesejahteraan masyarakat. Peningkatan pembangunan yang dilakukan oleh pemerintah memerlukan biaya yang tidak sedikit jumlahnya (Romandana, 2012). Besarnya pengeluaran pemerintah yang berkaitan dengan pembangunan harus dibarengi dengan penerimaan pemerintah yang juga harus semakin besar. Sumber penerimaan pemerintah diperoleh dari penerimaan dalam negeri dan pinjaman luar negeri. Sumber penerimaan pemerintah yang berasal dari dalam negeri misalnya seperti penerimaan negara bukan pajak (PNBP), penerimaan pajak dan hibah.

Penerimaan dari sektor pajak merupakan salah satu sumber utama pemerintah untuk membiayai pembangunan nasional dan pengeluaranpengeluaran lainnya (Cahyani dan Jati, 2016). Berdasarkan lembaga pemungutnya, pajak dapat dibagi menjadi pajak pusat dan pajak daerah (Alabede et al., 2011). Salah satu jenis penerimaan pajak daerah dapat diperoleh melalui Pajak Kendaraan Bermotor (PKB). PKB merupakan salah satu pajak daerah yang membiayai pembangunan daerah provinsi. Instansi yang menangani pembayaran PKB adalah Dinas Pendapatan Daerah (Dispenda) melalui Kantor Bersama Sistem Administrasi Manunggal dibawah Satu Atap (SAMSAT) yang merupakan kerja sama tiga instansi terkait, yaitu Dispenda Provinsi Bali, Kepolisian RI dan Asuransi Jasa Raharja (Widnyani dan Suardana, 2016).

Kantor Bersama SAMSAT Tabanan merupakan tempat para wajib pajak PKB di Kabupaten Tabanan melakukan pembayaran pajak kendaraan bermotornya. Banyaknya jumlah kendaraan bermotor di Kabupaten Tabanan menyebabkan penerimaan PKB di Kantor Bersama SAMSAT Tabanan semakin 
ISSN: 2302-8556

E-Jurnal Akuntansi Universitas Udayana

Vol.25.2.November (2018): 1506-1533

meningkat. Bila dilihat dari perkembangan selama lima tahun terakhir, perkembangan jumlah kendaraan bermotor yang tercatat di Kabupaten Tabanan tahun 2013-2017 disajikan pada Tabel 1 berikut.

Tabel 1.

Jumlah Kendaraan Bermotor yang Tercatat di Kabupaten Tabanan Tahun 2013 - 2017

\begin{tabular}{clrrrrr}
\hline & & \multicolumn{5}{c}{ Tahun } \\
\cline { 3 - 6 } No. & Jenis Kendaraan & $\mathbf{2 0 1 3}$ & $\mathbf{2 0 1 4}$ & $\mathbf{2 0 1 5}$ & $\mathbf{2 0 1 6}$ & $\mathbf{2 0 1 7}$ \\
\hline 1 & Sedan & 2.467 & 2.394 & 2.487 & 2.633 & 2.692 \\
2 & Jeep & 2.967 & 2.997 & 3.227 & 3.455 & 3.678 \\
3 & Minibus & 15.552 & 17.070 & 18.961 & 21.219 & 23.590 \\
4 & Bus & 633 & 607 & 623 & 641 & 701 \\
5 & Pick Up & 9.078 & 9.989 & 10.927 & 11.520 & 11.987 \\
6 & Truck & 5.415 & 5.595 & 5.744 & 5.844 & 5.860 \\
7 & Sepeda Motor & 271.849 & 292.162 & 309.860 & 325.175 & 338.313 \\
& Jumlah (Unit) & 307.961 & 330.814 & 351.829 & 370.487 & 386.821 \\
\hline
\end{tabular}

Sumber: Data diolah, 2018

Tabel 1. menunjukkan jumlah kendaraan bermotor yang tercatat di Kantor Bersama SAMSAT Tabanan dari tahun 2013-2017 terus mengalami peningkatan. Peningkatan jumlah kendaraan bermotor tersebut disebabkan oleh faktor -faktor seperti tingginya daya beli masyarakat dan meningkatnya kebutuhan masyarakat terhadap alat transportasi. Tingginya daya beli masyarakat tidak terlepas dari perkembangan teknologi yang sangat pesat khususnya di bidang transportasi dan semakin banyaknya jenis kendaraan yang ditawarkan oleh dealer-dealer. Semakin tinggi jumlah kendaraan bermotor yang beredar akan menyebabkan semakin meningkatnya jumlah wajib pajak PKB di Kabupaten Tabanan.

Kepatuhan wajib pajak dapat didefinisikan sebagai perilaku seseorang wajib pajak yang mematuhi seluruh kewajiban perpajakannya serta menggunakan seluruh haknya dengan mengacu pada peraturan perpajakan yang berlaku (Ersania dan Lely, 2018). Kepatuhan wajib pajak merupakan salah satu penunjang yang 
mampu meningkatkan Pendapatan Asli Daerah. Banyaknya jumlah wajib pajak PKB, seharusnya berpengaruh pada penerimaan pemerintah yang bersumber dari pajak khususnya PKB yang seharusnya juga meningkat. Namun di Kantor Bersama SAMSAT Tabanan jumlah denda yang tercatat masih cukup besar artinya masih banyak wajib pajak di wilayah Kabupaten Tabanan yang tidak patuh dalam memenuhi kewajibannya. Denda PKB berupa sanksi administrasi timbul karena wajib pajak tidak membayar kewajiban perpajakannya dengan tepat waktu.

Tabel 2.

Jumlah Objek Kendaraan yang Telah Melaksanakan Kewajiban Perpajakannya, Pokok Penerimaan dan Denda di Kantor Bersama SAMSAT Tabanan Tahun 2013-2017

\begin{tabular}{cccccc}
\hline No. & Tahun & Jumlah (Unit) & Pokok (Rp) & Denda (Rp) & Jumlah (Rp) \\
\hline 1 & 2013 & 205.392 & 61.614 .708 .100 & 1.902 .594 .500 & 63.517 .302 .600 \\
2 & 2014 & 213.269 & 70.096 .793 .100 & 3.226 .214 .800 & 73.323 .007 .900 \\
3 & 2015 & 217.062 & 75.432 .220 .600 & 4.077 .862 .000 & 79.510 .082 .600 \\
4 & 2016 & 214.998 & 86.930 .408 .200 & 2.527 .950 .645 & 89.458 .358 .845 \\
5 & 2017 & 216.327 & 105.402 .716 .000 & 4.473 .715 .175 & 109.876 .431 .175 \\
\multicolumn{5}{l}{ Sumber: Data diolah, 2018 }
\end{tabular}

Tabel 2. menunjukkan bahwa denda PKB yang terhutang oleh wajib pajak mengalami peningkatan pada tahun 2013 hingga tahun 2015 dan mengalami fluktuasi pada tahun 2015 hingga tahun 2017. Kesadaran wajib pajak dapat dilihat dari jumlah denda PKB di Kantor Bersama SAMSAT Tabanan dan denda tersebut dapat mencerminkan kepatuhan wajib pajak. Jumlah denda paling kecil terjadi pada tahun 2013 dan jumlah denda paling besar terjadi pada tahun 2017, dari data tersebut maka jumlah kepatuhan wajib pajak paling tinggi terjadi pada tahun 2013.

Berdasarkan Tabel 1. dan Tabel 2. dapat dilihat bahwa selama lima tahun terakhir jumlah kendaraan bermotor dan jumlah penerimaan PKB mengalami 
peningkatan namun tidak diimbangi dengan kepatuhan wajib pajak untuk memenuhi kewajibannya membayar PKB, yang tercermin dari masih kurangnya jumlah objek kendaraan yang telah melaksanakan kewajiban perpajakannya dibandingkan dengan jumlah kendaraan yang tercatat dan denda yang cukup besar di Kantor Bersama SAMSAT Tabanan.

Tabel 3.

Persentase Tingkat Kepatuhan Wajib Pajak Kendaraan Bermotor di Kantor Bersama SAMSAT Tabanan Tahun 2013 -2017

\begin{tabular}{ccccc}
\hline No & Tahun & $\begin{array}{c}\text { Jumlah WP yang } \\
\text { Terdaftar }\end{array}$ & $\begin{array}{c}\text { Jumlah WP yang sudah } \\
\text { melaksanakan kewajiban }\end{array}$ & $\begin{array}{c}\text { Persentase Tingkat } \\
\text { Kepatuhan }\end{array}$ \\
\hline 1 & 2013 & 307.961 & 205.392 & $66,69 \%$ \\
2 & 2014 & 330.814 & 213.269 & $64,47 \%$ \\
3 & 2015 & 351.829 & 217.062 & $61,70 \%$ \\
4 & 2016 & 370.487 & 214.998 & $58,03 \%$ \\
5 & 2017 & 386.821 & 216.327 & $55,92 \%$ \\
\hline
\end{tabular}

Sumber: Data diolah, 2018

Berdasarkan Tabel 3. dapat dilihat persentase tingkat kepatuhan wajib pajak kendaraan bermotor di Kantor Bersama SAMSAT Tabanan terus mengalami penurunan, hal tersebut mencerminkan tingkat kepatuhan wajib pajak kendaraan bermotor masih sangat rendah. Rendahnya tingkat kepatuhan wajib pajak di Kabupaten Tabanan dipengaruhi oleh banyak faktor seperti kesadaran wajib pajak, sanksi perpajakan dan sosialisasi perpajakan.

Kondisi dimana wajib pajak mengetahui, mematuhi, dan melaksanakan kewajiban perpajakan dengan benar dan sukarela sering disebut dengan kesadaran wajib pajak (Megawangi dan Setiawan, 2017). Kesadaran wajib pajak yang baik akan membantu meningkatkan kepatuhan wajib pajak baik mendaftarkan diri, melaporkan dan membayarpajaknya (James \& Nobes 1997). Hasil penelitian yang dilakukan oleh Kesumasari dan Suardana (2018) mengenai pengaruh kesadaran 
wajib pajak pada kepatuhan wajib pajak orang pribadi di KPP Pratama Gianyar menemukan bahwa variabel kesadaran wajib pajak berpengaruh positif terhadap kepatuhan wajib pajak orang pribadi. Penelitian yang dilakukan Prawirasuta dan Setiawan (2016) menemukan bahwa kesadaran wajib pajak berpengaruh positif dan signifikan pada kepatuhan wajib pajak orang pribadi. Hasil penelitian Hidayati (2014) mengenai pengaruh kesadaran wajib pajak terhadap kepatuhan wajib pajak orang pribadi di KPP Pratama Surakarta menemukan bahwa variabel kesadaran wajib pajak tidak berpengaruh positif pada kepatuhan wajib pajak orang pribadi.

Sanksi perpajakan memiliki peran penting guna memberikan pelajaran bagi pelanggar pajak agar tidak meremehkan peraturan perpajakan.Menurut Suandy dalam Sari dan Wirakusuma (2018) sanksi perpajakan juga dapat menjadi jaminan bahwa wajib pajak akan mematuhi segala peraturan perpajakan yang berlaku. Doran (2009) mengatakan bahwa wajib pajak akan menghindari sanksi yang akan membuat biaya yang dikeluarkan lebih besar dibandingkan pada saat patuh dalam melaksanakan kewajiban perpajakannya.Hasil penelitian yang dilakukan oleh Yasa dan Jati (2017) menemukan bahwa sanksi perpajakan berpengaruh positif pada kepatuhan wajib pajak. Penelitian yang dilakukan Wirawan dan Noviari (2017) menemukan bahwa sanksi perpajakan berpengaruh positif terhadap kepatuhan wajib pajak orang pribadi. Hasil penelitian lain yang dilakukan oleh Larasati (2013) menunjukkan bahwa variabel persepsi tentang sanksi perpajakan tidak berpengaruh terhadap kepatuhan pelaporan wajib pajak orang pribadi. 
ISSN: 2302-8556

E-Jurnal Akuntansi Universitas Udayana

Vol.25.2.November (2018): 1506-1533

Salah satu upaya Direktorat Jenderal Pajak untuk meningkatkan kepatuhan wajib pajak adalah melalui sosialisasi perpajakan. Sosialisasi perpajakan merupakan upaya untuk memberikan pengertian, informasi, dan pembinaan kepada masyarakat mengenai segala sesuatu yang berhubungan dengan PKB dan perundang-undangan. Sosialisasi dapat dilakukan melalui media komunikasi, baik media cetak seperti surat kabar, majalah maupun media audio visual seperti radio atau televisi (Sulistianingrum, 2009). Hasil penelitian yang dilakukan Dharma dan Suardana (2014) menemukan bahwa sosialisasi perpajakan berpengaruh positif dan signifikan pada kepatuhan wajib pajak dalam membayar PKB. Hasil penelitian yang dilakukan Rusmayani dan Supadmi (2017) menemukan bahwa sosialisasi perpajakan berpengaruh positif pada kepatuhan wajib pajak kendaraan bermotor. Sementara itu, hasil penelitian yang dilakukan oleh Setyoningrum (2014) sosialisasi perpajakan tidak memberikan pengaruh terhadap kepatuhan wajib pajak.

Adanya ketidakkonsistenan hasil dari penelitian yang terkait dengan faktor-faktor yang memengaruhi kepatuhan wajib pajak mendorong penulis untuk menambahkan sosialisasi perpajakan sebagai variabel pemoderasi hubungan antara variabel bebas terhadap variabel terikat, dimana variabel moderasi ini nantinya dapat memperkuat atau bahkan memperlemah hubungan antara variabel bebas terhadap variabel terikat. Alasan penulis memilih sosialisasi perpajakan sebagai pemoderasi karena sosialisasi perpajakan merupakan upaya yang efektif untuk meningkatkan kepatuhan wajib pajak. Semakin sering dilakukan sosialisasi perpajakan maka kesadaran dan pemahaman masyarakat tentang perpajakan akan 
semakin meningkat dan diharapkan dapat mendorong masyarakat untuk melaksanakan kewajiban perpajakannya.

Penelitian ini bertujuan sebagai berikut: 1) Untuk memeroleh bukti pengaruh kesadaran wajib pajak pada kepatuhan wajib pajak dalam membayar PKB di Kantor Bersama SAMSAT Tabanan; 2) Untuk memeroleh bukti pengaruh sanksi perpajakan pada kepatuhan wajib pajak dalam membayar PKB di Kantor Bersama SAMSAT Tabanan; 3) Untuk memeroleh bukti sosialisasi perpajakan memoderasi pengaruh kesadaran wajib pajak pada kepatuhan wajib pajak dalam membayar PKB di Kantor Bersama SAMSAT Tabanan; 4) Untuk memeroleh bukti sosialisasi perpajakan memoderasi pengaruh sanksi perpajakan pada kepatuhan wajib pajak dalam membayar PKB di Kantor Bersama SAMSAT Tabanan.

Penelitian ini diharapkan dapat memberikan wawasan yang lebih mendalam mengenai bagaimana Theory of Planned Behavior bermanfaat dalam pemecahan masalah mengenai faktor -faktor yang dapat memengaruhi kepatuhan wajib pajak dalam membayar PKB. Diharapkan pula penelitian ini dapat memberikan kontribusi dalam kajian empiris dan dijadikan perbandingan maupun pengembangan dari penelitian sebelumnya.

Theory of Planned Behavior relevan untuk menjelaskan perilaku wajib pajak dalam mematuhi kewajiban perpajakannya. Behavior beliefs, normative beliefs dan control beliefs sebagai tiga faktor yang menentukan seseorang untuk berperilaku. Setelah terdapat tiga faktor tersebut, maka seseorang akan memasuki tahap intention, kemudian tahap terakhir adalah behavior. Tahap intention 
merupakan tahap dimana seseorang memiliki maksud atau niat untuk berperilaku, sedangkan behavior adalah tahap seseorang berperilaku (Mustikasari, 2007).

Theory of Planned Behavior relevan untuk menjelaskan perilaku wajib pajak dan adanya kesadaran wajib pajak dalam mematuhi kewajiban perpajakannya sehingga dapat meningkatkan kepatuhan wajib pajak. Behavioral beliefs adalah keyakinan individu akan hasil dari suatu perilaku dan evaluasi atas hasil tersebut. Keyakinan akan hasil dari suatu perilaku wajib pajak dapat dipengaruhi adanya kesadaran wajib pajak untuk berperilaku patuh. Semakin tinggi kesadaran wajib pajak, maka pemahaman dan pelaksanaan kewajiban perpajakan semakin baik sehingga dapat meningkatkan kepatuhan.

Penelitian yang dilakukan oleh Putri dan Jati (2014) menemukan bahwa kesadaran wajib pajak berpengaruh positif pada kepatuhan wajib pajak dalam membayar pajak kendaraan bermotor di Kantor Bersama SAMSAT Denpasar. Selain itu, Pratiwi dan Ery (2014) menemukan bahwa kesadaran wajib pajak berpengaruh positif terhadap kepatuhan wajib pajak. Berdasarkan teori dan penelitian sebelumnya, maka dapat dirumuskan hipotesis sebagai berikut.

$\mathrm{H}_{1}$ : Kesadaran wajib pajak berpengaruh positif pada kepatuhan wajib pajak kendaraan bermotor di Kantor Bersama SAMSAT Tabanan.

Berdasarkan Theory of Planned Behavior, sanksi administrasi terkait dengan perceived behavioral control karena sanksi dibuat untuk mendukung wajib pajak agar mematuhi peraturan administasi perpajakan. Sanksi pajak merupakan jaminan bahwa kententuan peraturan perundang - undangan perpajakan akan ditaati. Kepatuhan wajib pajak akan ditentukan berdasarkan 
persepsi wajib pajak tentang seberapa kuat sanksi perpajakan yang mendukung perilaku wajib pajak untuk taat pajak. Pemerintah membuat sanksi perpajakan untuk meningkatkan kepatuhan wajib pajak yang dikenakan kepada wajib pajak yang lalai dalam melaksanakan kewajiban perpajakannya.

Penelitian yang dilakukan Arabella dan Mangonting (2013) menemukan bahwa sanksi perpajakan berpengaruh positif terhadap kepatuhan wajib pajak. Selain itu, Putri dan Jati (2014) menyatakan jika semakin tegas dan berat sanksi perpajakan akan meningkatkan kepatuhan wajib pajak. Berdasarkan teori dan penelitian sebelumnya, maka dapat dirumuskan hipotesis sebagai berikut.

$\mathrm{H}_{2}$ : Sanksi perpajakan berpengaruh positif pada kepatuhan wajib pajak kendaraan bermotor di Kantor Bersama SAMSAT Tabanan.

Sosialisasi perpajakan sangat penting diberikan kepada wajib pajak dalam memenuhi kewajiban perpajakannya. Kesadaran wajib pajak akan lebih efektif jika Direktorat Jenderal Pajak mengadakan sosialisasi perpajakan. Adanya sosialisasi perpajakan ini, maka wajib pajak akan mendapatkan pengertian, informasi, dan pembinaan sehingga dapat meningkatkan kesadaran wajib pajak. Penelitan yang dilakukan Megawangi dan Setiawan (2017) menemukan bahwa Sosialisasi perpajakan mampu memoderasi pengaruh kesadaran wajib pajak pada kepatuhan wajib pajak badan di KPP Pratama Gianyar. Selain itu, Hasil penelitian yang dilakukan Rusmayani dan Supadmi (2017) menemukan bahwa sosialisasi perpajakan berpengaruh positif pada kepatuhan wajib pajak kendaraan bermotor. Berdasarkan uraian di atas dan penelitian sebelumnya, maka dapat dirumuskan hipotesis sebagai berikut. 
$\mathrm{H}_{3}$ : Sosialisasi perpajakan memperkuat pengaruh kesadaran wajib pajak pada kepatuhan wajik pajak kendaraan bermotor di Kantor Bersama SAMSAT Tabanan.

Sosialisasi tentang sanksi perpajakan sangat penting dilakukan agar wajib pajak mengetahui, memahami dan melaksanakan kewajiban pajak dengan baik. Kurangnya sosialisasi akan berdampak pada rendahnya pengetahuan masyarakat tentang sanksi perpajakan yang menyebabkan rendahnya kesadaran masyarakat untuk melaporkan dan membayar pajak yang pada akhirnya mungkin menyebabkan rendahnya tingkat kepatuhan wajib pajak. Adanya sosialisasi perpajakan serta diberikannya sanksi perpajakan yang tegas, akan berdampak pada meningkatnya kepatuhan wajib pajak.

Penelitian yang dilakukan Dharma (2014) menemukan bahwa sosialisasi perpajakan berpengaruh positif dan signifikan pada kepatuhan wajib pajak dalam membayar PKB. Selain itu, penelitian yang dilakukan oleh Cahyani dan Jati (2016) menunjukkan bahwa variabel sosialisasi perpajakan berpengaruh positif pada kepatuhan wajib pajak PKB di Kantor Bersama SAMSAT Denpasar. Berdasarkan uraian di atas dan penelitian sebelumnya, maka dapat dirumuskan hipotesis sebagai berikut.

$\mathrm{H}_{4}$ : Sosialisasi perpajakan memperkuat pengaruh sanksi perpajakan pada kepatuhan wajik pajak kendaraan bermotor di Kantor Bersama SAMSAT Tabanan.

\section{METODE PENELITIAN}

Penelitian ini menggunakan pendekatan kualitatif yang berbentuk asosiatif. Penelitian ini membahas mengenai Sosialisasi Perpajakan Memoderasi Pengaruh Kesadaran Wajib Pajak dan Sanksi Perpajakan pada Kepatuhan Wajib Pajak 
Kendaraan Bermotor (PKB) di Kantor Bersama SAMSAT Tabanan, maka disusun desain penelitian seperti dapat dilihat pada Gambar 1.

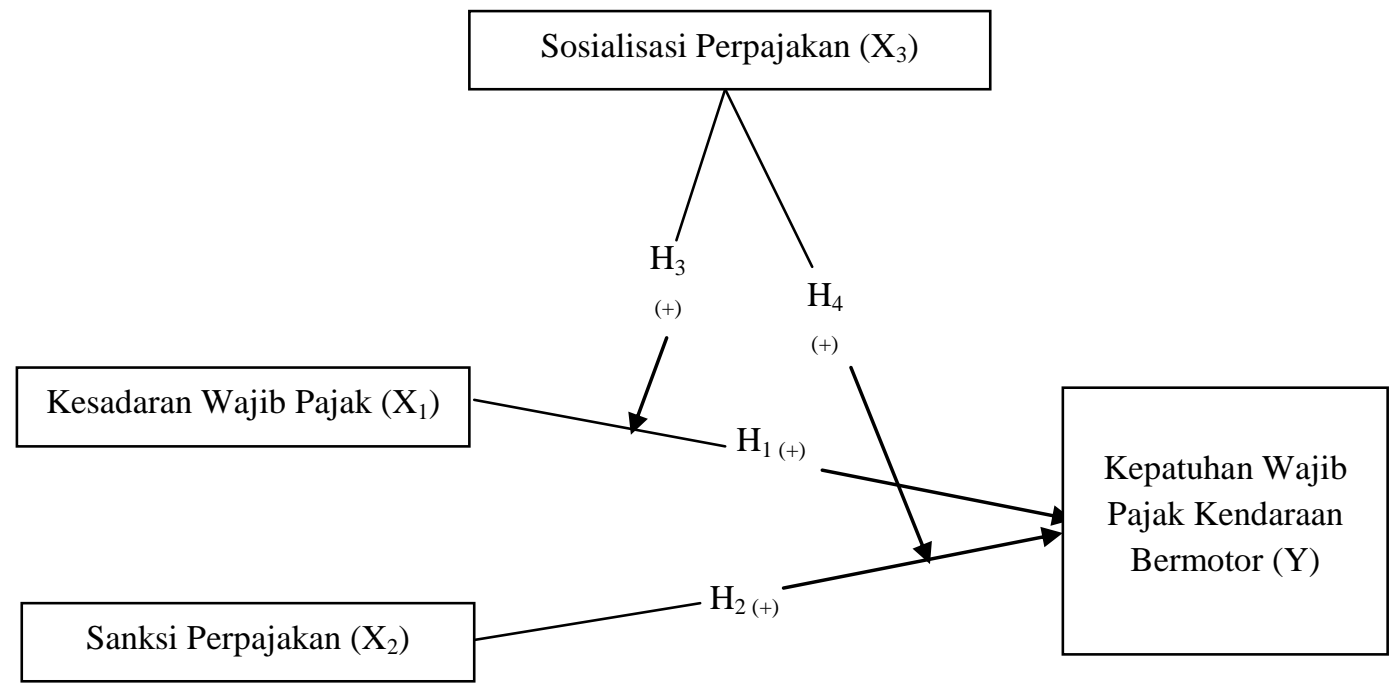

Sumber: Data diolah, 2018

\section{Gambar 1. Desain Penelitian}

Penelitian ini dilakukan di Kantor Bersama SAMSAT Tabanan yang beralamat di Jalan Katamso No 6 Tabanan. Penelitian ini menggunakan jenis data kuantitatif dan kualitatif. Data kuantitatif yang digunakan dalam penelitian ini adalah jumlah wajib pajak kendaraan bermotor, penerimaan pajak kendaaan bermotor, denda pajak kendaraan bermotor di Kabupaten Tabanan dan hasil dari pertanyaan-pertanyaan kuesioner yang telah dikuantitatifkan. Data kualitatif dalam penelitian ini adalah sejarah berdirinya Kantor Bersama SAMSAT Tabanan, struktur organisasi dan uraian tugas masing-masing bagian di Kantor Bersama SAMSAT Tabanan.

Berdasarkan sumbernya, data yang digunakan dalam penelitian ini adalah data primer dan data sekunder. Data primer dalam penelitian ini adalah hasil pengisian kuesioner oleh responden seputar variabel yang dimaksud. Data 
sekunder dalam penelitian ini adalah jumlah wajib pajak kendaraan bermotor, penerimaan pajak kendaaan bermotor, denda pajak kendaraan bermotor di Kabupaten Tabanan, sejarah berdirinya, struktur organisasi fungsional, dan uraian tugas masing- masing bagian Kantor Bersama SAMSAT Tabanan.

Variabel bebas dalam penelitian ini adalah Kesadaran Wajib Pajak $\left(\mathrm{X}_{1}\right)$ dan Sanksi Perpajakan $\left(\mathrm{X}_{2}\right)$. Variabel terikat dalam penelitian ini adalah Kepatuhan Wajib Pajak Kendaraan Bermotor (Y). Variabel moderating adalah variabel yang dapat memperkuat atau memperlemah hubungan antara variabel independen dengan variabel dependen. Variabel moderating dalam penelitian ini adalah Sosialisasi Perpajakan $\left(\mathrm{X}_{3}\right)$.

Kesadaran wajib pajak merupakan sebuah itikad baik seseorang untuk memenuhi kewajiban membayar pajak berdasarkan hati nuraninya yang tulus iklhas (Susilawati dan Budiartha, 2013). Menurut Pancawati dan Nila (2011) dalam Putra (2016) indikator yang digunakan untuk mengukur kesadaran membayar pajak antara lain sebagai berikut: 1) Pajak merupakan bentuk partisipasi dalam menunjang pembangunan daerah; 2) Penundaan pembayaran pajak dan pengurangan beban pajak sangat merugikan daerah; 3) Pajak ditetapkan dengan Undang-undang dan dapat dipaksakan; 4) Pemungutan pajak sesungguhnya dirasakan oleh mereka sendiri tapi tidak secara langsung dinikmati oleh para wajib pajak. Variabel ini di gunakan 4 pernyataan, yang dikembangkan oleh Susilawati (2013) dinilai dengan menggunakan skala likert 1-4.

Dalam undang-undang perpajakan dikenal dua macam sanksi perpajakan, yaitu sanksi administrasi dan sanksi pidana. Sanksi Pajak Kendaraan Bermotor 
I Made Gilang Hartana dan Ni Ketut Lely Aryani Merkusiwati. Sosialisasi...

diatur dalam Peraturan Daerah Provinsi Bali Nomor 1 Tahun 2011. Berdasarkan dari teori Undang- undang yang berlaku, pandangan tentang sanksi perpajakan tersebut diukur dengan indikator sebagai berikut: 1) Wajib pajak mengetahui adanya sanksi pajak kendaraan bermotor; 2) Wajib pajak membayar pajak kendaraan bermotor tepat waktu untuk menghindari sanksi; 3) Sudah sepantasnya wajib pajak yang tidak membayar pajak kendaraan bermotor dikenakan sanksi. Variabel ini digunakan 3 pernyataan, yang dikembangkan oleh Febriyanti (2017) dinilai dengan menggunakan skala likert 1-4.

Sosialisasi perpajakan merupakan upaya dari Dirjen Pajak untuk memberikan pengertian, informasi dan pembinaan kepada masyarakat dan wajib pajak mengenai segala sesuatu yang berhubungan dengan peraturan dan perundang - undangan perpajakan (Adiyati, 2009). Sosialisasi perpajakan tersebut dapat diukur dengan indikator sebagai berikut (Sulistianingrum, 2009). 1) Kegiatan penyuluhan yang diadakan oleh kantor SAMSAT mengenai PKB; 2) Brosur tentang pajak khususnya PKB; 3) Anda memperoleh informasi yang lengkap tentang PKB lewat internet; 4) Iklan perkembangan informasi tentang pajak (PKB) melalui surat kabar, majalah, jurnal atau layanan masyarakat di televisi. Variabel ini digunakan 4 pernyataan, yang dikembangkan oleh Pani (2014) dinilai dengan menggunakan skala likert 1-4.

Kepatuhan wajib pajak merupakan suatu keadaan dimana wajib pajak memenuhi semua kewajiban dan melaksanakan hak perpajakannya. Untuk mengukur kepatuhan wajib pajak dalam membayar pajak kendaraan bermotor menggunakan 3 pertanyaan yang dikembangkan oleh Januarta (2011) dalam Putra 
(2016), yaitu sebagai berikut: 1) Wajib pajak paham atau berusaha memahami ketentuan peraturan perundangundangan pajak kendaraan bermotor; 2) Wajib pajak membayar pajak kendaraan bermotor yang terutang tepat pada waktunya; 3) Wajib pajak membayar pajak kendaraan bermotor dalam jumlah yang sesuai dengan peraturan. Untuk mengukur kepatuhan wajib pajak dalam membayar pajak kendaraan bermotor menggunakan 3 item pernyataan disajikan menggunakan skala likert 1-4.

Populasi dalam penelitian ini adalah seluruh wajib pajak kendaraan bermotor yang terdaftar di Kantor Bersama SAMSAT Tabanan sampai dengan tahun 2017 yaitu sebanyak 386.821 wajib pajak. Sampel adalah bagian dari jumlah karakteristik yang dimiliki oleh populasi tersebut (Sugiyono, 2016:116). Metode penentuan sampel yang digunakan dalam penelitian ini adalah metode accidental sampling. Adapun yang menjadi responden dalam penelitian ini adalah seluruh wajib pajak pemilik kendaraan bermotor yang membayar pajak PKB di Kantor Bersama SAMSAT Tabanan. Besarnya ukuran sampel dihitung dengan menggunakan rumus Slovin (Siregar, 2013:34). Berdasarkan perhitungan jumlah sampel yang digunakan dalam penelitian ini sejumlah 100 (seratus) wajib pajak kendaraan bermotor milik pribadi di Kantor Bersama SAMSAT Tabanan.

Metode pengumpulan data pada penelitian ini menggunakan metode survei dengan teknik pengumpulan data yang digunakan berupa kuesioner. Jawabanjawaban responden diberikan nilai atau skor dengan menggunakan skala likert modifikasi dengan rentang skor terendah 1 sampai tertinggi adalah 4. Hasil jawaban kuesioner akan diberi nilai 4 poin untuk jawaban Sangat Setuju (SS), 3 
poin untuk jawaban Setuju (S), 2 poin untuk jawaban Tidak Setuju (TS), dan 1 poin untuk jawaban Sangat Tidak Setuju (STS).

Instrumen penelitian adalah suatu alat yang dapat digunakan untuk memeroleh, mengolah dan menginterprestasikan informasi yang diperoleh dari para responden yang dilakukan dengan menggunakan pola ukur yang sama (Siregar, 2013:46). Pengujian instrumen penelitian meliputi pengujian validitas dan pengujian reliabilitas. Analisis statistik deskriptif digunakan untuk memberikan informasi mengenai karakteristik variabel penelitian. Statistik deskriptif menjelaskan skala jawaban responden pada setiap variabel independen yang diukur dari nilai minimum, nilai maksimum, nilai rata-rata, dan standar devisiasi. Uji asumsi klasik terhadap model regresi yang digunakan dalam penelitian dilakukan untuk menguji apakah model regresi tersebut baik atau tidak. Uji asumsi klasik yang digunakan dalam penelitian ini adalah uji normalitas, uji multikolinearitas dan uji heteroskedastisitas.

Analisis regresi moderasi atau moderate regression analysis (MRA) merupakan aplikasi khususnya regresi linear berganda dimana dalam persamaan regresinya mengandung unsur interaksi (perkalian dua atau lebih variabel bebas) (Liana, 2009). MRA dipilih dalam penelitian ini karena dapat menjelaskan pengaruh variabel moderasi dalam memperkuat maupun memperlemah hubungan variabel bebas dengan variabel terikat. Penghitungan statistik dikatakan signifikan apabila nilai uji statistiknya berada dalam daerah kritis (daerah dimana $\mathrm{H}_{0}$ ditolak) dan sebaliknya disebut tidak signifikan apabila uji statistiknya berada dalam 
daerah dimana $\mathrm{H}_{0}$ diterima. Model regresi moderasi dalam penelitian ini ditunjukkan oleh persamaan berikut (Ghozali, 2016: 219).

$Y=\alpha+\beta_{1} X_{1}+\beta_{2} X_{2}+\mu$

$Y=\alpha+\beta_{1} X_{1}+\beta_{2} X_{2}+\beta_{3} X_{3}+\beta_{4} X_{1} X_{3}+\beta_{5} X_{2} X_{3}+\mu$

Keterangan:

$\mathrm{Y} \quad=$ Kepatuhan Wajib Pajak Kendaraan Bermotor

$\alpha \quad=$ Konstanta

$\beta_{1}-\beta_{5}=$ Koefisien

$\mathrm{X}_{1} \quad=$ Kesadaran Wajib Pajak

$\mathrm{X}_{2} \quad=$ Sanksi Perpajakan

$\mathrm{X}_{3}=$ Sosialisasi Perpajakan

$\mu \quad=$ Standard Error

\section{HASIL DAN PEMBAHASAN}

Uji validitas digunakan untuk mengukur sah valid tidaknya suatu kuesioner. Kuesioner dapat dinyatakan valid apablia pertanyaan atau pernyataan pada kuesioner mampu mengungkapkan sesuatu yang akan diukur oleh kuesioner tersebut (Ghozali, 2016:52). Hasil uji validitas pada penelitian ini menunjukkan bahwa seluruh indikator pernyataan dalam variabel kesadaran wajib pajak, sanksi perpajakan, sosialisasi perpajakan dan kepatuhan wajib pajak memenuhi syarat validitas karena nilai korelasi antara skor tiap pernyataan dengan skor total menunjukkan hasil yang signifikan berniai positif dan nilainya lebih dari 0,30 .

Suatu kuesioner dikatakan reliabel atau handal jika jawaban seseorang terhadap pernyataan adalah konsisten atau stabil dari waktu ke waktu dan memberikan nilai Cronbach"s Alpha > 0,60 (Sugiyono, 2016:178). Hasil uji reliabilitas pada penelitian ini menunjukkan bahwa variabel-variabel yang digunakan dalam penelitian ini adalah reliabel karena keseluruhan variabel 
memiliki Cronbach”s Alpha yang lebih besar dari 0,60 sehingga layak digunakan menjadi alat ukur instrumen kuesioner dalam penelitian ini.

Tabel 4.

Hasil Uji Statistik Deskriptif

\begin{tabular}{lccccc}
\hline \multicolumn{1}{c}{ Variabel } & N & Min. & Max. & Mean & Std. Deviasi \\
\hline Kesadaran Wajib Pajak $\left(\mathrm{X}_{1}\right)$ & 100 & 4,00 & 15,25 & 11,1194 & 3,28091 \\
Sanksi Perpajakan $\left(\mathrm{X}_{2}\right)$ & 100 & 3,00 & 11,60 & 8,6728 & 2,43885 \\
Sosialisasi Perpajakan $\left(\mathrm{X}_{3}\right)$ & 100 & 4,00 & 15,18 & 11,3898 & 3,35657 \\
Kepatuhan Wajib Pajak $(\mathrm{Y})$ & 100 & 3,00 & 11,03 & 8,2754 & 2,71417 \\
\hline
\end{tabular}

Sumber: Data diolah, 2018

Hasil uji statistik deskriptif pada Tabel 4. menunjukan bahwa variabel kesadaran wajib pajak $\left(\mathrm{X}_{1}\right)$ memiliki nilai minimum sebesar 4,00 , nilai maksimum sebesar 15,25, mean sebesar 11,12 dan standar deviasi sebesar 3,28. Hal ini menunjukan terjadi perbedaan nilai kesadaran wajib pajak yang diteliti dengan nilai rata-ratanya sebesar 3,28 . Variabel sanksi perpajakan $\left(\mathrm{X}_{2}\right)$ memiliki nilai minimum sebesar 3,00, nilai maksimum sebesar 11,60, mean sebesar 8,67 dan standar deviasi sebesar 2,44. Hai ini menunjukan terjadi perbedaan nilai sanksi perpajakan yang diteliti dengan nilai rata-ratanya sebesar 2,44.

Variabel sosialisasi perpajakan $\left(\mathrm{X}_{3}\right)$ memiliki nilai minimum sebesar 4,00, nilai maksimum sebesar 15,18, mean sebesar 11,39 dan standar deviasi sebesar 3,36. Hal ini menunjukan terjadi perbedaan nilai sosialisasi perpajakan yang diteliti dengan nilai rata-ratanya sebesar 3,39. Variabel kepatuhan wajib pajak kendaraan bermotor (Y) memiliki nilai minimum sebesar 3,00, nilai maksimum sebesar 11,03, mean sebesar 8,28 dan standar deviasi sebesar 2,71. Hal ini menunjukkan terjadi perbedaan nilai kepatuhan wajib pajak kendaraan bermotor yang diteliti dengan nilai rata-ratanya sebesar 2,71. 
Uji normalitas bertujuan untuk menguji apakah dalam model regresi, variabel terikat (dependent) dan variabel bebas (independent) memiliki distribusi normal atau tidak.Uji normalitas dalam penelitian ini menggunakan KolmogorovSmirnov test. Hasil uji normalitas pada penelitian ini menunjukan bahwa nilai signifikansi model regresi dalam penelitian ini $>0,05$. Hal ini berarti model regresi dalam penelitian ini berdistribusi normal.

Uji multikolinearitas bertujuan untuk menguji apakah model regresi ditemukan adanya korelasi antar variabel bebas (independen) (Ghozali, 2016:103). Hasil uji multikolinearitas pada penelitian ini menunjukkan nilai tolerance dari masing-masing variabel lebih besar dari 0,10 dan nilai VIF diperoleh lebih kecil dari 10. Hal ini menunjukkan tidak adanya kolerasi antara sesama variabel bebas dalam model regresi sehingga dapat disimpulkan bahwa tidak terdapat masalah multikolinearitas.

Uji heteroskedastisitas dilakukan untuk mengetahui apakah dalam model regresi terjadi ketidaksamaan varian dari residual satu pengamatan ke pengamatan lainnya (Ghozali, 2016:134). Hasil uji heteroskedastisitas pada penelitian ini menunjukkan bahwa nilai signifikansi masing-masing variabel lebih besar dari 0,05 yang berarti variabel tersebut bebas heteroskedasitas. 
Tabel 5.

Hasil Uji Analisis Regresi Linear Berganda

\begin{tabular}{lcccccc}
\hline \multirow{2}{*}{ Keterangan } & \multicolumn{2}{c}{$\begin{array}{c}\text { Unstandardized } \\
\text { Coefficients }\end{array}$} & $\begin{array}{c}\text { Standardized } \\
\text { Coefficients }\end{array}$ & t & Sig. & $\begin{array}{c}\text { Hasil Uji } \\
\text { Hipotesis }\end{array}$ \\
\cline { 2 - 5 } & $\mathbf{B}$ & Std. Error & Beta & & & \\
\hline (Constant) & $-0,177$ & 0,680 & & $-0,260$ & 0,795 & \\
Kesadaran wajib & 0,371 & 0,062 & 0,448 & 5,978 & 0,000 & $\mathrm{H}_{1}$ Diterima \\
Pajak $\left(\mathrm{X}_{1}\right)$ & & & & & & $\mathrm{H}_{2}$ Diterima \\
Sanksi & 0,499 & 0,083 & 0,449 & 5,986 & 0,000 & \\
Perpajakan $\left(\mathrm{X}_{2}\right)$ & & & & & & \\
$R$ & & 0,794 & & & & \\
$R$ Square & & 0,630 & & & & \\
Adjusted $R$ Square & & 0,622 & & & & \\
F Hitung & 82,485 & & & & & \\
Sig. $F$ & 0,000 & & & & &
\end{tabular}

Hasil pengujian pada Tabel 5. menunjukkan bahwa koefisien determinasi yaitu nilai Adjusted $R$ Square sebesar 0,622. Ini berarti sebesar 62,2\% variabel Kesadaran Wajib Pajak $\left(\mathrm{X}_{1}\right)$ dan Sanksi Perpajakan $\left(\mathrm{X}_{2}\right)$ menjelaskan variasi dari Kepatuhan Wajib Pajak Kendaraan Bermotor (Y), sedangkan sisanya sebesar 37,8\% dipengaruhi oleh faktor lainnya. Berdasarkan Tabel 5. diperoleh nilai $\mathrm{F}$ hitung sebesar 82,485 dengan tingkat signifikansi sebesar 0,000. Karena signifikansi F hitung lebih kecil dari 0,05, maka dapat disimpulkan bahwa model regresi yang digunakan untuk menguji pengaruh variabel independen terhadap variabel dependen layak digunakan.

Pada Tabel 5. dapat dilihat bahwa nilai t hitung Kesadaran Wajib Pajak $\left(\mathrm{X}_{1}\right)$ sebesar 5,978 dengan tingkat signifikansi sebesar 0,000 lebih kecil dari $\alpha=$ 0,05. Hasil ini menunjukan bahwa Kesadaran Wajib Pajak berpengaruh positif dan signifikan pada Kepatuhan Wajib Pajak Kendaraan Bermotor di Kantor Bersama Samsat Tabanan. Berdasarkan analisis regresi linear berganda diperoleh 
nilai $\beta_{1}$ sebesar 0,371 dan nilai signifikansi sebesar 0,000 yang lebih kecil dari $\alpha=$ 0,05, maka hipotesis pertama $\left(\mathrm{H}_{1}\right)$ diterima.

Adanya pengaruh positif yang signifikan antara kesadaran wajib pajak pada kepatuhan wajib pajak kendaraan bermotor di Kantor Bersama SAMSAT Tabanan menunjukkan bahwa wajib pajak yang memiliki kesadaran perpajakan yang baik akan cenderung untuk patuh dalam melaksanakan kewajiban perpajakannya. Hal ini berarti semakin tinggi kesadaran wajib pajak, maka kepatuhan wajib pajak kendaraan bermotor di Kabupaten Tabanan akan semakin meningkat. Hasil penelitian ini selaras dengan penelitian yang dilakukan Putri (2014) dan Pratiwi (2014) yang menyatakan bahwa kesadaran wajib pajak berpengaruh positif pada kepatuhan wajib pajak.

Pada Tabel 5. dapat dilihat bahwa nilai t hitung Pajak Kendaraan Bermotor dengan tarif progresif sebesar 5,986 dengan tingkat signifikansi sebesar 0,000 lebih kecil dari $\alpha=0,05$. Hasil ini menunjukan bahwa Sanksi Perpajakan berpengaruh positif dan signifikan pada Kepatuhan Wajib Pajak Kendaraan Bermotor di Kantor Bersama Samsat Tabanan. Berdasarkan analisis regresi linear berganda diperoleh nilai $\beta_{2}$ sebesar 0,499 dan nilai signifikansi sebesar 0,000 yang lebih kecil dari $\alpha=0,05$, maka hipotesis kedua $\left(\mathrm{H}_{2}\right)$ diterima.

Adanya pengaruh positif yang signifikan antara sanksi perpajakan pada kepatuhan wajib pajak kendaraan bermotor di Kantor Bersama SAMSAT Tabanan menunjukkan bahwa pandangan tentang pengenaan sanksi perpajakan yang akan lebih merugikan wajib pajak apabila tidak melakukan pembayaran pajak menjadi 
faktor pendorong bagi wajib pajak untuk memenuhi kewajiban perpajakannya. Sehingga salah satu cara untuk menghindari sanksi perpajakan yaitu dengan melakukan pembayaran pajak tepat pada waktunya atau tidak melewati jangka waktu yang ditetapkan. Hal ini berarti semakin tinggi sanksi perpajakan, maka kepatuhan wajib pajak kendaraan bermotor di Kabupaten Tabanan akan semakin meningkat. Hasil penelitian ini selaras dengan penelitian yang dilakukan oleh Arabella (2013) dan Putri (2014) yang menyatakan bahwa sanksi perpajakan berpengaruh positif terhadap kepatuhan wajib pajak.

Penelitian ini menggunakan model Moderated Regression Analysis (MRA) untuk mengetahui hubungan antara pengaruh Kesadaran Wajib Pajak dan Sanksi Perpajakan pada Kepatuhan Wajib Pajak Kendaraan Bermotor dengan Sosialisasi Perpajakan sebagai moderasi.

Tabel 6.

Hasil Uji Moderated Regression Analysis

\begin{tabular}{|c|c|c|c|c|c|c|}
\hline \multirow[t]{2}{*}{ Keterangan } & \multicolumn{2}{|c|}{$\begin{array}{l}\text { Unstandardized } \\
\text { Coefficients }\end{array}$} & \multirow{2}{*}{$\begin{array}{c}\begin{array}{c}\text { Standardized } \\
\text { Coefficients }\end{array} \\
\text { Beta }\end{array}$} & \multirow[t]{2}{*}{$\mathbf{T}$} & \multirow[t]{2}{*}{ Sig. } & \multirow[t]{2}{*}{$\begin{array}{l}\text { Hasil Uji } \\
\text { Hipotesis }\end{array}$} \\
\hline & B & Std. Error & & & & \\
\hline (Constant) & 0,332 & 1,566 & & 0,212 & 0,833 & \\
\hline $\mathrm{X} 1$ & $-0,193$ & 0,167 & $-0,233$ & $-1,155$ & 0,251 & \\
\hline $\mathrm{X} 2$ & 0,618 & 0,217 & 0,555 & 2,843 & 0,005 & \\
\hline X3 & 0,255 & 0,160 & 0,315 & 1,591 & 0,115 & \\
\hline $\mathrm{X} 1 \mathrm{X} 3$ & 0,035 & 0,014 & 0,768 & 2,402 & 0,018 & $\mathrm{H}_{3}$ Diterima \\
\hline $\mathrm{X} 2 \mathrm{X} 3$ & $-0,027$ & 0,019 & $-0,462$ & $-1,403$ & 0,164 & $\mathrm{H}_{4}$ Ditolak \\
\hline$R$ & 0,846 & & & & & \\
\hline R Square & 0,715 & & & & & \\
\hline Adjusted $R$ Square & 0,700 & & & & & \\
\hline F Hitung & 47,225 & & & & & \\
\hline Sig. $F$ & 0,000 & & & & & \\
\hline
\end{tabular}

Berdasarkan Tabel 6. menunjukkan bahwa nilai adjusted $R$ square model sebesar 0,700 artinya sebesar 70\% variasi dari Kepatuhan Wajib Pajak Kendaraan 
Bermotor dipengaruhi oleh Kesadaran Wajib Pajak, Sanksi Perpajakan dan Sosialisasi Perpajakan, sedangkan sisanya sebesar 30\% dijelaskan oleh variabel lainnya. Dari hasil uji statistik F pada Tabel 6. menunjukan bahwa nilai F hitung sebesar 47,225 dengan nilai signifikansi sebesar 0,000 lebih kecil dari nilai $\alpha=$ 0,05. Hal ini menunjukkan bahwa model persamaan dalam penelitian ini layak untuk digunakan.

Berdasarkan hasil pengujian pada Tabel 6. pengaruh variabel interaksi antara kesadaran wajib pajak dengan sosialisasi perpajakan $\left(\mathrm{X}_{1} \mathrm{X}_{3}\right)$ pada Kepatuhan Wajib Pajak Kendaraan Bermotor (Y) menunjukkan tingkat signifikansi $\mathrm{t}_{\text {hitung }}$ sebesar 0,018 lebih kecil dari $\alpha=0,05$, maka $\mathrm{H}_{0}$ ditolak dan $\mathrm{H}_{3}$ diterima. Hal ini berarti bahwa sosialisasi perpajakan mampu memoderasi pengaruh kesadaran wajib pajak pada kepatuhan wajib pajak kendaraan bermotor di Kantor Bersama SAMSAT Tabanan. Nilai koefisien regresi kesadaran wajib pajak dan sosialisasi perpajakan $\left(\mathrm{X}_{1} \mathrm{X}_{3}\right)$ sebesar 0,035 menjelaskan bahwa sosialisasi perpajakan memperkuat pengaruh kesadaran wajib pajak pada kepatuhan wajib pajak kendaraan bermotor di Kantor Bersama SAMSAT Tabanan. Hasil penelitian ini menunjukkan sosialisasi perpajakan dapat memengaruhi kesadaran seseorang dalam membayar pajak. Sosialisasi perpajakan yang dilakukan oleh SAMSAT akan menyebabkan wajib pajak menjadi sadar akan pentingnya mematuhi peraturan pajak yang telah ditentukan.

Berdasarkan hasil analisis regresi moderasi pada Tabel 6. menunjukkan nilai signifikansi sebesar 0,164 yang lebih besar dari $\alpha=0,05$ maka hipotesis keempat $\left(\mathrm{H}_{4}\right)$ ditolak. Hal ini berarti bahwa sosialisasi perpajakan tidak 
mampumemoderasi pengaruh sanksi perpajakan pada kepatuhan wajib pajak kendaraan bermotor di Kantor Bersama SAMSAT Tabanan. Tidak mampunya sosialisasi perpajakan dalam memoderasi pengaruh sanksi perpajakan pada kepatuhan wajib pajak kendaraan bermotor disebabkan karena sanksi perpajakan bersifat tetap, artinya besaran sanksi perpajakan yang dikenakan sudah ditentukan oleh pemerintah jadi semakin sering dilakukan sosialisasi perpajakan tidak akan dapat memengaruhi hubungan atau pengaruh sanksi perpajakan pada kepatuhan wajib pajak.

\section{SIMPULAN}

Berdasarkan hasil penelitian dan pembahasan, maka simpulan penelitian ini yaitu:

1) Kesadaran Wajib Pajak berpengaruh positif pada Kepatuhan Wajib Pajak Kendaraan Bermotor di Kantor Bersama SAMSAT Tabanan. Artinya semakin tinggi Kesadaran Wajib Pajak untuk membayar kewajiban perpajakannya, maka Kepatuhan Wajib Pajak dalam membayar Pajak Kendaraan Bermotor akan semakin meningkat; 2) Sanksi Perpajakan berpengaruh positif pada Kepatuhan Wajib Pajak Kendaraan Bermotor di Kantor Bersama SAMSAT Tabanan. Artinya semakin tinggi Sanksi Perpajakan yang dikenakan, maka Kepatuhan Wajib Pajak Kendaraan Bermotor semakin meningkat; 3) Sosialisasi Perpajakan mampu memerkuat pengaruh Kesadaran Wajib Pajak pada Kepatuhan Wajib Pajak Kendaraan Bermotor di Kantor Bersama SAMSAT Tabanan. Artinya semakin sering dilakukan Sosialisasi Perpajakan maka akan meningkatkan Kesadaran Wajib Pajak untuk patuh atau melaksanakan kewajiban perpajakannya; 4) Sosialisasi Perpajakan tidak mampu memederasi hubungan antara Sanksi 
ISSN: 2302-8556

E-Jurnal Akuntansi Universitas Udayana

Vol.25.2.November (2018): 1506-1533

Perpajakan pada Kepatuhan Wajib Pajak Kendaraan Bermotor di Kantor Bersama SAMSAT Tabanan. Artinya semakin sering atau tidak dilakukan Sosialisasi Perpajakan tidak akan memengaruhi pengaruh Sanksi Perpajakan pada Kepatuhan Wajib Pajak Kendaraan Bermotor.

Saran yang dapat diberikan untuk penelitian selanjutnya hasil penelitian ini diharapkan mampu mendorong peneliti untuk mengamati variabel-variabel lain yang memengaruhi kepatuhan wajib pajak kendaraan bermotor, karena hasil Adjusted $R$ square $\left(R^{2}\right)$ sebesar 70 persen yang berarti masih ada 30 persen faktor lain seperti pengetahuan perpajakan, kewajiban moral dan akuntabilitas pelayanan publik yang dapat memengaruhi kepatuhan wajib pajak kendaraan bermotor.

\section{REFERENSI}

Adiyati, Tatiek. (2009). Pengaruh Sosialisasi Perpajakan Terhadap Kepatuhan Wajib Pajak Pada KPP Pratama Jakarta Kebayoran Lama. Jurnal: UPN Veteran Jakarta.

Alabede, James O., Zaimah Bt. Zainol Affrin dan Kamil Md. Idris. 2011. Tax Service Quality and Compliance Behaviour in Nigeria: Do Taxpayer's Financial Condition and Risk Preference Play Any Moderating Role?. European Journal of Economics, Finance and Administrative Sciences, 35: p: 90-108.

Arabella, Oentari Fuadi dan Yeni Mangonting. 2013. Pengaruh Kualitas Pelayanan Petugas Pajak, Sanksi Perpajakan dan Biaya Kepatuhan Pajak Terhadap Kepatuhan Wajib Pajak UMKM. Tax \& Accounting Review, 1 (1), h: 35-42.

Astana, I Wayan Sugi dan Ni Ketut Lely Aryani Merkusiwati. 2017. Pengaruh Penerapan Sistem Administrasi Perpajakan Modern dan Kesadaran Wajib Pajak pada Kepatuhan Wajib Pajak. E-Jurnal Akuntansi Universitas Udayana, 18 (1), h:818-846. ISSN: 2302-8556.

Cahyani, I Made Wahyu dan I Ketut Jati. 2016. Pengaruh Kesadaran, Sosialisasi, Akuntabilitas Pelayanan Publik dan Sanksi Perpajakan Pada Kepatuhan 
Wajib Pajak Kendaraan Bermotor. E-Jurnal Akuntansi Universitas Udayana, 16 (3), h:2342-2373. ISSN:2302-8556.

Dewi, Luh Putu Santi Krisna dan Ni Ketut Lely Aryani Merkusiwati. 2018. Pengaruh Kesadaran Wajib Pajak, Sanksi Perpajakan, E-Filing, dan Tax Amnesty Terhadap Kepatuhan Pelaporan Wajib Pajak. E-Jurnal Akuntansi Universitas Udayana, 22(2),h:1626-1655. ISSN:2302-8556.

Dharma, Gede Pani Esa dan Ketut Alit Suardana. 2014. Pengaruh Kesadaran Wajib Pajak, Sosialisasi Perpajakan, dan Kualitas Pelayanan Terhadap Kepatuhan Wajib Pajak dalam Membayar PKB dan BBNKB. E-Jurnal Akuntansi Universitas Udayana. 8(2), h: 340-353.

Doran, Michael. 2009. Tax Penaltie and Tax Comliance. Harvard Journal On Legislation, Vol.46, page: 111-116.

Ersania, Gusti Ayu Raisa dan Ni Ketut Lely Aryani Merkusiwati. 2018. Pengaruh Penerapan E-System Perpajakan Terhadap Tingkat Kepatuhan Wajib Pajak Orang Pribadi. E-Jurnal Akuntansi Universitas Udayana,22(3),h:1882-1908. ISSN:2302-8556.

Ghozali, Imam. 2016. Aplikasi Analisis Multivariative Dengan Program IBM SPSS 23.Semarang: Badan Penerbit Universitas Diponogoro.

Hidayati, Iva Farida. 2014. Analisis Pengaruh Kesadaran Wajib Pajak, Pengetahuan dan Pemahaman tentang Peraturan Perpajakan, Efektivitas Sistem Perpajakan, Pelayanan Fiskus dan Sanksi Pajak terhadap Kepatuhan Wajib Pajak Orang Pribadi. Skripsi .Fakultas Ekonomi dan Bisnis Universitas Muhammadiyah Surakarta.

James, S. and Nobes, C. 1997. The Economics of Taxation, Principle, Policy and Practice. Europe: Prentice Hall.

Kesumasari, Ni Kadek Intania dan Ketut Alit Suardana. 2018. Pengaruh Pengetahuan Perpajakan, Kesadaran dan Pengetahuan Tax Amnesty pada Kepatuhan WPOP di KPP Pratama Gianyar. E-Jurnal Akuntansi Universitas Udayana, 22(2), h:1503-1529. ISSN:2302-8556.

Larasati, Leningrat Dyta. 2013. Pengaruh Persepsi tentang Sanksi Perpajakan, Kesadaran Wajib Pajak dan Karakteristik Wajib Pajak pada Kepatuhan Pelaporan Wajib Pajak Orang Pribadi (Studi Kasus pada Kantor Pelayanan Pajak Pratama Boyolali). Skripsi. Fakultas Ekonomi dan Bisnis Universitas Muhammadiyah Surakarta.

Liana, Lie. 2009. Penggunaan MRA dengan SPSS untuk Menguji Pengaruh Variabel Moderating terhadap Hubungan antara Variabel Independen dan 
Variabel Dependen. Jurnal Teknologi Informasi Dinamik, 12(2).hal.9097.

Megawangi, Cokorda Agung Meggy dan Putu Ery Setiawan. 2017. Sosialisasi Perpajakan Memoderasi Pengaruh Kesadaran Wajib Pajak dan Kualitas Pelayanan pada Kepatuhan Wajib Pajak Badan. E-Jurnal Akuntansi Universitas Udayan,. 19(3): h:2348-2377.ISSN:2302-8556.

Mustikasari, Elia. 2007. Kajian Empiris tentang Kepatuhan Wajib Pajak Badan di Perusahaan Industri Pengolahan di Surabaya. Simposium Nasional Akuntansi X.

Pani. 2014. Pengaruh Kesadaran Wajib Pajak, Sosialisasi Perpajakan, Kualitas Pelayanan Pajak Pada Kepatuhan Wajib Pajak. Skripsi. Fakultas Ekonomi dan Bisnis Universitas Udayana.

Pratiwi, I Gusti Ayu Made Agung Mas Andriani dan Putu Ery Setiawan. 2014. Pengaruh Kesadaran Wajib Pajak, Kualitas Pelayanan, Kondisi Keuangan Perusahaan Dan Persepsi Tentang Sanksi Perpajakan Pada Kepatuhan Wajib Pajak Reklame di Dinas Pendapatan Kota Denpasar. EJurnal Akuntansi Universitas Udayana, 1 (2), h: 456-473. ISSN: 23028556.

Prawirasuta, Made Wisnu, Putu Ery Setiawan. 2016. Integritas sebagai Pemoderasi Pengaruh Sanksi Pajak dan Kesadaran Wajib Pajak pada Kepatuhan Wajib Pajak Orang Pribadi di Kantor Pelayanan Pajak Pratama Badung Utara. E-Jurnal Akuntansi Universitas Udayana, 16(2): 1661-1686. ISSN : 2302-8556.

Putri, Siswanto, I Ketut Jati. 2014. Faktor-Faktor yang Mempengaruhi Kepatuhan Wajib Pajak dalam Membayar Pajak Kendaraan Bermotor di Denpasar. E-Jurnal Akuntansi Universitas Udayana, 2(3): h: 661-677.

Romandana, Anggraini. 2012. Pengaruh Pengetahuan Pajak, Persepsi tentang Petugas Pajak dan Sistem Administrasi Pajak terhadap Tingkat Kepatuhan Wajib Pajak Orang Pribadi. Artikel Ilmiah. Sekolah Tinggi Ilmu Ekonomi Perbanas.

Rusmayani, Ni Made Lisa dan Ni Luh Supadmi. Pengaruh Sosialisasi, Pengetahuan, Sanksi dan Kualitas Pelayanan pada Kepatuhan Wajib Pajak kendaraan Bermotor. E-Jurnal Akuntansi Universitas Udayana, 20(1):h: 173-201. ISSN:2302-8556.

Setyoningrum, dkk. 2014. Analisis Pengaruh Sosialisasi Perpajakan, Kualitas Pelayanan Fiskus dan Sanksi Perpajakan Terhadap Kepatuhan Wajib Pajak Orang Pribadi di Kantor Pelayanan Pajak Pratama Manado. Jurnal $E M B A$. Universitas Sam Ratulangi, Manado. 
Siregar, Syofian. 2013. Metode Penelitian Kuantitatif: Perhitungan Manual \& SPSS. Edisi 1. Jakarta: Prenadamedia Group.

Sugiyono, Prof. Dr. 2016. Metode Penelitian Bisnis (Pendekatan Kuantitatif, Kualitatif, dan $R \& D)$. Bandung: Alfabeta.

Susilawati, Ketut Evi dan Ketut Budiartha. 2013. Pengaruh Kesadaran Wajib Pajak, Pengetahuan Pajak, Sanksi Perpajakan Dan Akuntabilitas Pelayanan Publik Pada Kepatuhan Wajib Pajak Kendaraan Bermotor. EJurnal Akuntansi Universitas Udayana, 4 (2), h: 345-357.

Torgler, B. (2005). Direct Democracy and Tax Morale. European Journal of Political Economy, 21(3), h: 525-531.

Undang - Undang Republik Indonesia Nomor 28 Tahun 2009. Pajak Daerah dan Retribusi Daerah.

Widnyani, Ida Ayu Dewi dan Ketut Alit Suardana. 2016. Pengaruh Sosialisasi, Sanksi dan Persepsi Akuntabilitas Terhadap Kepatuhan Wajib Pajak Dalam Membayar Pajak Kendaraan Bermotor. E-Jurnal Akuntansi Universitas Udayana, 16 (3), h: 2176-2203. ISSN: 2302-8556.

Wirawan, Ida Bagus Ngurah Ari Putra dan Naniek Noviari. 2017. Pengaruh Penerapan Kebijakan Tax Amnesty dan Sanksi Perpajakan Terhadap Kepatuhan Wajib Pajak Orang Pribadi. E-Jurnal Akuntansi Universitas Udayana, 21(3), h: 2165-2194. ISSN: 2302-8556.

Yasa, I Putu Risky Perdana dan I Ketut Jati. 2017. Kondisi Keuangan Wajib Pajak Pemoderasi Pengaruh Sanksi Perpajakan, Kesadaran Wajib Pajak pada Kepatuhan Wajib Pajak. E-Jurnal Akuntansi Universitas Udayana, 19(2), h:1521-1550. ISSN: 2302-8556. 